\title{
A large-scale model of the three first stages of the mammalian olfactory system implemented with spiking neurons
}

\author{
Bernhard Kaplan ${ }^{1 *}$, Simon Benjaminsson ${ }^{1}$, Anders Lansner ${ }^{1,2}$ \\ From Twentieth Annual Computational Neuroscience Meeting: CNS*2011 \\ Stockholm, Sweden. 23-28 July 2011
}

In this work we present a large-scale three stage model of the early mammalian olfactory system, including the olfactory epithelium (OE), the olfactory bulb (OB) and the olfactory (piriform) cortex (OC). All neurons in the network are modeled with a single or few compartments using the Hodgkin-Huxley formalism and are implemented in the NEURON simulator for parallel execution $[1,2]$. We investigate the dynamics of the network response to odorants and its performance in odor classification experiments.

The OE model comprises families of olfactory receptor neurons (ORNs) with different sensitivities, each family expressing one type of olfactory receptor (OR) with a vector of affinity values for each ligand [3]. These different ORN families connect to distinct glomeruli and mitral cells (MT) according to a hypothesized wiring scheme to form a fuzzy interval code for odorant concentration in the OB, i.e. each MT cell responds within a certain range of odorant concentration and these ranges overlap for different MT cells within one glomerulus. Mitral cells in different glomeruli respond independently to an odourant forming a sparse and distributed code in the OB, i.e. only a fraction of MT cells in different glomeruli is active when an odorant is present. The OC is modeled by a modular attractor network of pyramidal cells and inhibitory interneurons [4]. The OB response patterns are used to self-organize a projection to the $\mathrm{OC}$ based on learning algorithms employing ideas from machine learning (mutual information between the MT responses, multi-dimensional scaling, vector quantization and Hebbian learning) [5,6]. As a result, odourant

\footnotetext{
* Correspondence: bkaplan@kth.se

'Department of Computational Biology, Royal Institute of Technology,

Stockholm, S-10044, Sweden

Full list of author information is available at the end of the article
}

responses are represented by a sparse distributed code in the OC.

Results from runs with network sizes comprising thousands of model neurons show that this biophysically plausible network model generates response patterns of cells reminding of their real counterparts (see Figure 1), produces attractor dynamics in the olfactory cortex, and is able to discriminate between the different trained odors. We investigate effects of the model size, backprojections from $\mathrm{OC}$ to $\mathrm{OB}$, study the performance of the model in discriminating mixtures of odorants and compare Calcium concentration in the olfactory cortex with experimental measurements [7].

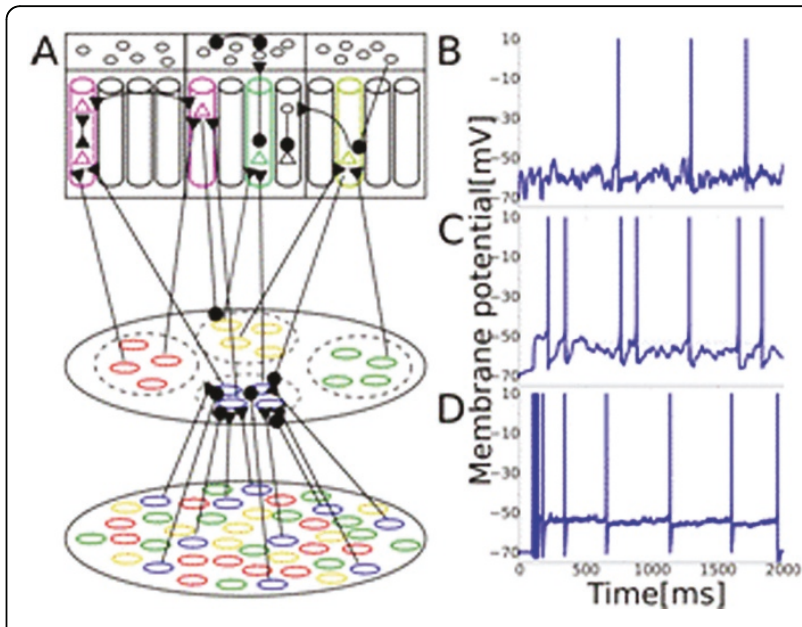

Figure 1 Schematic of the model (A) and sample membrane potentials of a pyramidal cell (B), a mitral cell (C) and an olfactory receptor neuron (D)

\section{C) Biomed Central}

(C) 2011 Kaplan et al; licensee BioMed Central Ltd. This is an open access article distributed under the terms of the Creative Commons Attribution License (http://creativecommons.org/licenses/by/2.0), which permits unrestricted use, distribution, and reproduction in any medium, provided the original work is properly cited. 


\section{Acknowledgements}

European FP7 projects FACETS-ITN, NeuroChem

\section{Author details}

'Department of Computational Biology, Royal Institute of Technology, Stockholm, S-10044, Sweden. ${ }^{2}$ Department of Computational Biology, Stockholm University, Stockholm, S-11421, Sweden.

Published: 18 July 2011

\section{References}

1. Pospischil M, Toledo-Rodriguez M, Monier C, Piwkowska Z, Bal T, Frégnac $Y$, Markram H, Destexhe A: Minimal Hodgkin-Huxley type models for different classes of cortical and thalamic neurons. Biological cybernetics 2008, 99(4-5):427-441.

2. Davison AP, Feng J, Brown D: Dendrodendritic inhibition and simulated odor responses in a detailed olfactory bulb network model. J Neurophysiol 2003, 90(3):1921-1935.

3. Firestein S: How the olfactory system makes sense of scents. Nature 2001, 413(6852):211-218

4. Lundqvist $\mathrm{M}$, Compte $\mathrm{A}$, Lansner $\mathrm{A}$ : Bistable, irregular firing and population oscillations in a modular attractor memory network. PLOS Computational Biology 2010, 6(6):1-12.

5. Benjaminsson S, Fransson P, Lansner A: A novel model-free data analysis technique based on clustering in a mutual information space: application to resting-state fmri. Front. Syst Neurosci 2010, 4:1-8.

6. Lansner A, Benjaminsson S, Johansson C: From ANN to biomimetic signal processing. In "Biologically inspired signal processing for chemical sensing". Springer;Gutierrez A. and Marco S. 2008:33-42.

7. Stettler DD, Axel R: Representations of odor in the piriform cortex. Neuron 2009, 63(6):854-864.

doi:10.1186/1471-2202-12-S1-P185

Cite this article as: Kaplan et al: A large-scale model of the three first stages of the mammalian olfactory system implemented with spiking neurons. BMC Neuroscience 2011 12(Suppl 1):P185.

\section{Submit your next manuscript to BioMed Central} and take full advantage of:

- Convenient online submission

- Thorough peer review

- No space constraints or color figure charges

- Immediate publication on acceptance

- Inclusion in PubMed, CAS, Scopus and Google Scholar

- Research which is freely available for redistribution

Submit your manuscript at www.biomedcentral.com/submit
Biomed Central 